\title{
FACTORS INFLUENCING LEARNERS' SATISFACTION IN AN OPEN E-LEARNING ENVIRONMENT
}

\author{
Sirje Klaos \\ Tallinn University, Estonia
}

\begin{abstract}
A number of new open learning environments have risen aside to common e-learning environments. Wikiversity is an open environment to all community members. Students' behaviours change in the community creation process, and their self-satisfaction impacts learning. The study methodology is qualitative content analysis, and the data is collected from students' blogs, online and focus group interviews. Data is based on a monitored course for bachelor students of special pedagogy $(n=21)$. There was a possibility to test and assess modern e-learning technologies and use a socio-constructive learning process. The results are studied in light of social-exchange theory. The outcome of this study indicated that learners' satisfaction increases with free access to fellow students' works, full and equal membership of the community and an opportunity to compare oneself to the others. The future research should focus on optimization of policies and sustainable development in education to establish successful exchange systems.
\end{abstract}

Key words: satisfaction, e-learning, self-directed learning, social-constructive learning

\section{Introduction}

The satisfaction of learners in the classroom has been extensively researched (Astin, 1993; DeBourgh, 1999; Navarro \& Shoemaker, 2000; Bolliger \& Martindale, 2004) just as the contentment of learners in an e-study environment with limited access (Artino \& Stephens, 2009). However, not so much research has been conducted in open study environments. Wikiversity is a diffused e-study environment, which is not strictly limited and does not have a login, restricted users or set up procedures. Thus, Wikiversity is a place with a new approach to e-studies. "It is a training delivered on a computer (including CD-ROM, Internet, or intranet) that is designed to support individual learning or organizational performance goals" (Clark \& Mayer, 2007, p. 7).

The creators of educational software cannot ignore the influences of technology that impact social life. Certain different computer systems or web browsers can also be a problem for some learners. Thus, it is important that the tools are compatible with each other. 
For instance, the equal access to Web Sites has been ensured and HTML (XHTML) - language standards have been agreed on. The conditions can be consulted on World Wide Web Consortium page.

Web 2.0 and various social media programmes are based on cooperation and internet access which forces both learners and teachers to be aware of such concepts and problems. For instance, the well-known social environment Facebook does not pass an access control, hence, these pages are not valid. Although the learners nowadays use mobile communication tools (smart phones, notebooks), information is not always available. This is a problem for learners with special needs whose financial possibilities are often limited. According to UNESCO Declaration of Human Rights, every human being has a right to have access to scientific and technological knowledge (UNESCO, 2005). Therefore, we should not forget that, if the equal opportunities and free access are ensured to the learner, it leads to certain expectations. Valuing the connection between education and working life becomes increasingly important. According to studies conducted in Finland, the greatest obstacles for the execution of learning through work result from a lack of co-operation between education establishments and enterprises in planning training programmes and building partnerships. A dynamic and many-sided partnership between education and working life creates new opportunities to meet the challenges of the future (Niemi \& Ruohotie, 2002). On the one hand, we are open to the innovation; on the other hand, we have to follow the rules and regulations of community.

The learners of the aforementioned (Wikiversity) environment have to realize that their contribution is not connected solely with their role as recipients but their active participation presupposes the characteristics of a self-directed learner. The notion of a selfdirected learner has to be considered one of the main educational tools of an adult student (Cunningham, 2010). Brookfield (1986) showed that self-directed studying is something more than a modified transfer of knowledge. He (Brookfield, 1986) defined it as follows:

Self-directed learning in this second sense occurs when learners come to regard knowledge as relative and contextual, to view the value frameworks and moral codes informing their behaviours as cultural constructs, and to use this altered perspective to contemplate ways in which they can transform their personal and social worlds (p. 47).

Thus, real self-directed learning arises from the student's internal transformation that has been planned and is in accordance with one's self-discipline. The latter brings about social change.

\section{Review of literature}

A contented learner is the one who has perceived his/her experience of the educational institution as an acquisition of education supplied by a trusted educational body (Astin, 1993). One of the determiners of the learner's satisfaction with him/herself is selfperception, when he/she feels that his/her expectations are fulfilled or even surpassed and 
he/she has gained one more enriching experience (Juillerat, 1995). The same is confirmed by the latest surveys showing that, if the student's expectations are in accordance with or surpass the aims set for him/herself at the beginning of the course, he/she appears to be content. If the expectations are higher than reality, the student is clearly dissatisfied (Artino \& Stephens, 2009).

Furthermore, the learner can be seen as a consumer. Giese and Gote (2000) have in the past 30 years studied twenty different definitions connected with satisfaction. On the basis of literature, validated data groups and personal interviews, they (Giese \& Gote, 2000) have arrived at the conclusion that the contentment of an e-learner is influenced by three main components: 1) it is a sum of intensively variable affective conditions (such as 'I like', 'I feel good' or 'I feel comfortable'); 2) a certain time period which varies with the situation but still, in most cases, has a limited duration; 3) the core of satisfaction is study content, i.e. choice, acquisition and use of the product.

Therefore, learner's satisfaction can be defined as a sum of intensively variable affective conditions that can be observed via asynchronic e-learning activities. The latter are, however, stimulated by different central factors such as content, user interface, learners' community, adjustability and realization of the studied material (Giese \& Gote, 2000; Wang, 2003).

The learner's satisfaction increases if the studied material is important for him/her, immediately related to his/her life and linked to the achievement of the long or short term studying goals, which have been interpreted as his/her own (Soini, Pietarinen, \& Pyhältö 2008). At the same time, acquisition of experience in the learning process cannot yet be considered a sufficient factor for ensuring student's contentment. Finnish researchers (Pyhältö, Pietarinen, Soini, \& Huusko, 2008) have discovered that if the learner experiences him/herself as an active doer and participant in cooperation with others, an even greater feeling of satisfaction can be achieved. Thus, the more time students invest in their studies, the higher is the level of their efforts and the more they study (Demaris \& Kristonis, 2008). The aforementioned devoted students can be characterized as self-regulated learners who efficiently monitor their studying experience in different ways, organizing and trying out new information they have acquired, observing their intellectual processes and seeking help if they do not grasp the meaning of the material. They are positively motivated and believe in their abilities and learning values (Schunk \& Zimmerman, 1998; Boekaerts, Pintrich, \& Zeidner, 2000).

It has been found that highly motivated and independent learners need e-learning environment just because of its autonomous character compared to a traditional classroom (Dabbagh \& Kitsantas, 2004). Moreover, academic motivation is also influenced by the learner's age (Ke and Xie, 2009).

Another important condition securing satisfaction is the simplicity and userfriendliness of the technology employed in the course (Belanger \& Jordan, 2000). The students who are frustrated by the course technology have a lower satisfaction level (Chong, 1998; Hara \& Kling, 2000; Bolinger \& Martindale, 2004). Dubois' (1996) survey showed that older learners are not so apt to use the technology because they have family and work duties. 
Social Exchange Theory (SET) supplies a theoretical framework and gives guidelines on how to increase students' participation activity. The crux of the aforementioned theory is the explanation offered by Homans (1958):

Social behaviour is an exchange of goods, material goods but also non-material ones, such as the symbols of approval or prestige. Persons that give much to others try to get much from them, and persons that get much from others are under pressure to give much to them. This process of influence tends to work out at equilibrium to a balance in the exchanges. For a person in an exchange, what he gives may be a cost to him, just as what he gets may be a reward, and his behaviour changes less as the difference of the two, profit, tends to a maximum" (p. 606).

Hall (2001) suggests four main factors which ensure motivation and obliges members of a community to share their knowledge:

1. personal needs: expectations that are accepted during the activity and ensure useful information in return;

2. reputation: learner feels that he has been visible and able to influence other community members with his opinion;

3. altruism or a notion of efficiently shared knowledge in one's community which has been publicly approved;

4. tangible reward.

In this study, the author has made use of the general format of open learning environment Wikiversity within a landscape of social media tools and services to support students' selfsatisfaction in open learning environments.

\section{Sample and methods}

\section{Overview of the course, participants and landscape of social media}

The bachelor's level course "Educational Technology and Special Needs" was designed to challenge participants into advancing their dispositions for self-directing learning to understand the problems of educational technology that people with special needs have with the support of social media tools and service.

The choice of the aforementioned course was determined by three different factors.

1. The target group the course participants will be working with in future is unique and forms a minority in society. However, UNESCO Declaration of Human Rights and the EU Council of Ministers' decree for 2006 - 2015 states that the rights of the people with special needs have to be protected and their full participation in society has to be promoted.

2. An awareness of the various possibilities of ICT which are relevant and accessible for the people with special needs is to be highlighted. 
3. These possibilities are to be regarded in a fresh perspective, and using open elearning environment which includes the instruments of WEB 2.0 is to be considered.

21 undergraduate students (3rd course) majoring in special pedagogy participated in an e-learning course lasting for half a semester in autumn 2009. These participants were 12 full-time students and nine distance learning students. The students' age range was from 20 to 54 .

The form for this particular e-learning course was blended learning, where full-time students had a chance to meet each other once a week in a computer class. Distance learning students lacked this opportunity, hence, they met only twice during the course, at the beginning and at the end. The course lasted for seven weeks.

The course facilitator used a distributed technological landscape (Figure 1) of social media, leaving aside any centralized and close systems hosted by institution (Fiedler \& Kieslinger, 2006). The central core of this selection was open e-learning environment Wikiversity, where students' were provided with an updated overview of ongoing activities, necessary materials and links. All participants could add themselves their contact data: email, weblog and homepage addresses. A synchronic communication tool "Skype" connected facilitators and students in real time conversation. Personal blogs were used for selfreflection and writing essays and the simplest program Notepad was used for making homepages. The reasons for opting to use Notepad were the following: this program does not need installation, it belongs to the operating system Windows (i.e. it does not require additional expenses from the users) and has the simplest text editing system, where the user can enter a clear HTML code and which is compatible with other high technology-based tools (cell phones, IPad, IPod, etc.) The choice of the latter instruments was determined by the awareness of the problems encountered by people with special needs in contemporary information society and the ability to evaluate the accessibility of web-based materials for people with special needs (Kikkas, 2009).

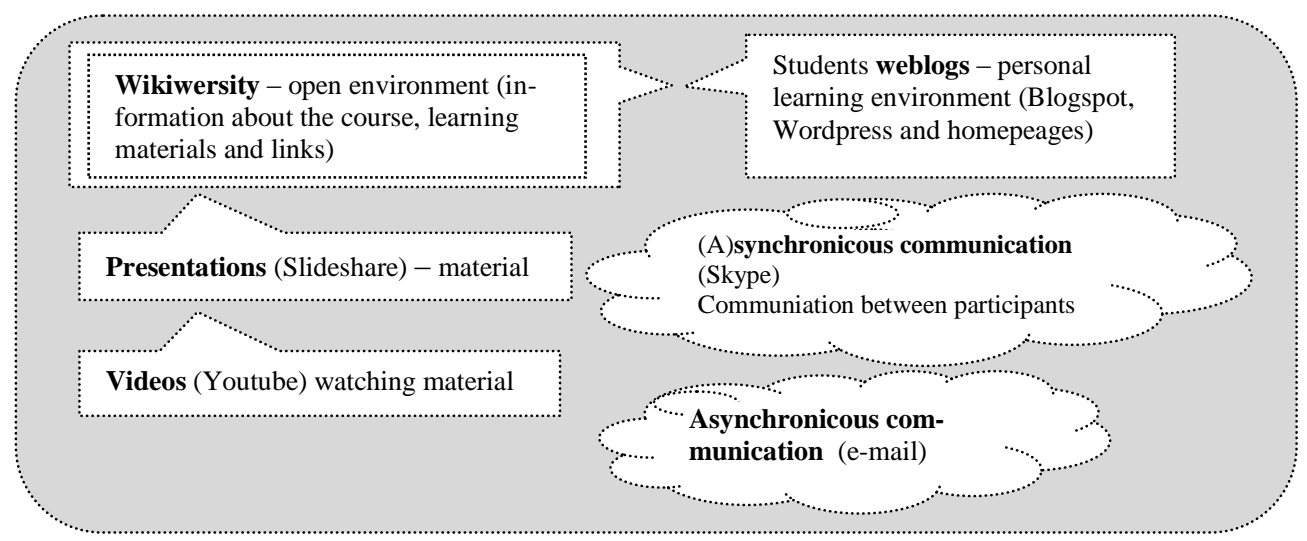

Figure 1. Landscape of tools and services used in the course 


\section{Course framework}

The course had two general objectives. Firstly, to introduce and perceive the role of information technology (IT) in involving people with special needs through social-constructive learning methods and the support of social media to people with pedagogical background. Secondly, to provide students with a basic practical knowledge of web-making and the ability to become familiar with the accessibility of web materials for users with different disabilities.

Special attention was paid to the notion of self-directed learning and self-satisfaction. Hence, two assignments were completed, one individually and the other in peer-groups. Students had to think of a study activity and come up with the real working technological landscape that would support this particular activity. Reflection was done in an essay format, where students were asked to review a survey of reading materials and their actual learning process of making a simple homepage. All individual and group work was supported and mediated by the tools and services the students had selected.

Students were given complete freedom and full responsibility for their activities. They were encouraged to take control over the objectivities and the means (straight connection SET 1 factors) (Hall, 2001). Although learners had been given a final deadline for assignment completion, they were encouraged to follow their own pace while respecting overall duration of the course. To foster personal responsibility, course facilitator provided different reading materials on various related topics (special needs in different eras; Internet, World Wide Web; (X)HTML and CSS; support of different technological solutions for special needs; accessibility and standards on the Web; characteristics of Internet communication; IT and special needs). The mentioned topics are crucial in the everyday work of the future special pedagogue (connection SET 3 and 4 factors) (Hall, 2001).

\section{Research design}

This research is based on content analysis of inductive and deductive category application. The inductive category is based on the students' personal Weblogs (Krippendorff, 2004). The deductive category application is to formulate a criterion of definition derived from theoretical background and a research question, which determines the aspects of the textual material taken into account (Mayring, 2000). The implementation of the two different categories of content analysis is regarded to enhance the reliability of the results of the given research.

The aim of this qualitative analysis is to study students' satisfaction in open e-learning environments.

1. Supporting students' satisfaction and understanding course design, a discussion on the issue "Educational technology and people with special needs" to identify and describe self-directedness and intended changes for the course design was initiated. Overall purpose of Wikiversity and understanding Openness was based on the different factors leading to satisfaction. 
2. The section of design and implementation of resource for practical work refers to the actual teaching process where the change in student reflection was observed, their personal characteristics presented in Weblogs were analysed and social aspect (i.e. what they said about cooperation) was considered.

3. An analysis of students' self-satisfaction in light of Social Exchange Theory was carried out, and reflection of students' perceptions of their experiences while participating in the course was organized. This study seeks to find out what connections and patterns emerged as a result.

\section{Research questions}

The purpose of qualitative analysis was to study students' satisfaction in open e-learning environments. Social media and learning tasks promoting self-directing were used and students' responses to that learning situation were investigated. This study seeks to find out the answers to the four questions.

1. What factors support students' self-satisfaction?

2. Which challenges are presented by practical work (individual and peer) to foster positive self-perception?

3. What is sustainability when talking about learning environment or how to change and increase students' activeness to participate?

\section{Data collection and analysis}

21 students participated in the course and the focus was on data which revealed students' cognitive and emotional aspects (attitudes, feelings, thoughts). Data was collected in the form of students' essays, interviews and reflections about their feelings and experiences. This technique of qualitative analysis was recommended by Miles and Huberman (1994) and procedures of inductive category. The analysis involved data reduction through writing and rewriting the findings' section.

The findings are organized to focus on the research questions. Students' pseudonyms were used in the discussion.

\section{Students' reflections on satisfaction factors}

The factors of satisfaction were analysed from the following aspects: personal characteristics, self-directedness and social aspect. At the beginning of the course, students had many expectations as well as fears concerning this new experience. The tasks were tackled according to the person's level of responsibility, independence, motivation, initiative or ability to adjust, according to some of the responses provided.

S1: Topic itself is interesting but not treated much, and that is why I hesitated a bit at first. 
S2: I approached the subject with big hesitation and prejudice, I admit there was even fear.

S3: Expectations were high, I hoped to get some good tips how to compile study materials on the Internet myself.

The students experienced satisfaction if they were aware of their own study needs and objectives that they wanted to achieve. For instance, one of the characteristics of selfdirectedness is time management skills.

S4: Work was organized systematically week by week (in the same order the tasks were set) and such work allocation was actually perfect.

S5: I tried to complete one task every week, but then there was a short break and overcoming it took time and effort.

S6: Because I knew that this project would take a lot of time, effort and patience, I decided to start early, so there would be time to experiment/discover as well as make mistakes, but still manage to finish the project in time.

S7: One of the most positive aspects of the course was that you could plan your own time and that way you could concentrate more deeply on these exercises.

\section{Challenges of practical work about feedback}

The interviews with the students indicate that the given task was more targeted to the external rather than internal motivation.

S8: As at the beginning of this project many of us had no contact with blogging, we did not know what to do exactly. We were not quite sure how to complete the tasks. Every beginning is hard, it was proven again by this subject.

S9: Making the web page turned out to be more difficult than I expected. Despite my previous experience with making a web page, it did not go without obstacles.

Despite sharing an authentic social situation with students, it became apparent that the language used as a medium of knowledge was not understood by everyone the same way. Understandings within the community were different or problems were approached from different angles (Jonassen, 2004).

The problem actually emerged because initially nobody had questions about how to complete the task or how things should be done. But, after receiving feedback and discussing amongst themselves how everyone was handling a particular task, it came out how differently people understood the same exercise.

S10: When the homepage was up and passed the validator, I thought-yes, I did it. But, after looking over my homepage, the lecturer gave me more tips and recommendations of how my homepage would look even better and how to gain even more points from it. It is done now! 
Constant interaction and encouragement during the course supported the student (every task was followed by feedback) and made the learning experience more effective. Presenting and demonstrating the task step-by-step was of great help.

S11: I expected the teacher to provide feedback on the work done and the questions which arose and I got it as much as I needed. I was very satisfied with the structure and arrangement of this course, and I expect more courses like that in the future. It's an excellent form of studying for correspondence course students, and why not in some subjects for full-time students.

$S$ 12: I expected help of all kind from my lecturer. I would have received it if I had been more active myself. However, I got answers and suggestions for every question I asked.

\section{Dependence of satisfaction factors on sustainable learning environment and change in students' activeness}

Students' satisfaction with sustainable learning environment arises if they feel included, if they can share their knowledge, if it is an open environment. At the beginning of the course, students do not pay much attention to it; however, at the end of the course they are able to bring out the most important aspects.

S4: All expectations were fulfilled. Even in a larger scope than at first expected since the feedback provided by the lecturer was very good. I did not expect that kind of a co-operation.

S6: The course finished quickly, but, at the same time, it was very informative and beneficial. I am now more knowledgeable in IT and more liable to help people with special needs in this domain.

S13: During this course, we discussed many things with my course mates, how different people understood the tasks, just to be sure. Many of us shared the same problems, most of us thought that making our own homepages was the most difficult task, and, for many of us, it was our first homepage ever.

The study results are presented in accordance with SET and based on deductive content analysis using descriptive statistics. Responses were collected by focus group interviews and the respondents were divided into age groups according to the length of their work experience: Group 1 (work experience 0) - age 20-21; Group 2 (work experience 1 year) age 22-24; Group 3 (work experience more than 5 years) - age 29-42. Each group comprised from four to six people (Table 1). 
Table 1. Frequency of students' satisfaction according to the four factors of SET

\begin{tabular}{cccc}
\hline Groups & A1 & A2 & A3 \\
\hline I & 2 & 3 & 1 \\
\hline II & 1 & 3 & 0 \\
\hline III & 1 & 4 & 0 \\
\hline & B1 & B2 & B3 \\
\hline I & 3 & 2 & 1 \\
\hline II & 0 & 3 & 1 \\
\hline III & 0 & 2 & 3 \\
\hline & C1 & C2 & C3 \\
\hline I & 3 & 3 & 0 \\
\hline II & 1 & 3 & 0 \\
\hline III & 1 & 3 & 1 \\
\hline & D1 & D2 & D3 \\
\hline I & 4 & 2 & 0 \\
\hline II & 1 & 3 & 0 \\
\hline III & 3 & 2 & 0 \\
\hline
\end{tabular}

The results can be viewed from the left to the right. Based on the four factors of SET (Hall, 2001), the responses were divided into the three categories:

1. Personal needs. A1 - high (values knowledge and skills); A2 - moderate (values knowledge or skills); A3 - low (does not prefer knowledge to skills or vice versa).

2. Reputation and sharing knowledge. B1 - visible to the peers, persistent observer of others; B2 - shares opinions only when guided, observes the others; B3 - does not share opinions, observes the others only at times, does not meet deadlines, shares opinions rarely.

3. Altruism or shared knowledge. $\mathrm{C} 1$ - sharing knowledge is highly valued, is interested in enhancing peers' well-being; $\mathrm{C} 2$ - sharing knowledge with peers is moderately valued; C3 - is not interested in peers' well-being and does not share knowledge with them.

4. Tangible and mental reward. D1 - the result and feedback of the course is highly valued, is aware of the direct material profit that could be gained in the future or current profession; D2 - the result and feedback of the course is moderately valued, is aware of the professional prospects; D3 - the gained knowledge is not valued, is unable to connect the acquired knowledge to the profession.

\section{Discussion}

The findings suggest that this course provoked both self-satisfaction and dissatisfaction. Reflections on the activities varied considerably among students. The student's selfsatisfaction supports good feelings, his/her expectations are fulfilled and even fostered (S4, S6) (Juillerat, 1995).

Self-satisfaction also depends on learner's personal characteristics (affective, cognitive, connotative aspects), i.e. emotions, attitudes, concepts and activities. The essay shows that students as users of social media express their emotions and knowledge (S8). When 
they learn to use weblogs and see facilitator's feedback, the participants' attitudes to the subject and their learning strategies change (S11). The same point is brought out by Giese and Gote (2000), i.e. the core of satisfaction is choice, acquisition and use of the product or people's development and growth.

Cognitive aspects (attitudes and understanding) foster motivation and self-directedness (S4, S6, S7). Students are positively motivated and believe in their abilities, which was also found by Boekaerts, Pintrich and Zeidner (2000). Connotative aspects in this study show different comprehension of the activities, which led to practical tasks being challenging. Feedback was negative due to several reasons: missing competence (S9, S13), bad time management skills (S5) etc.

After the completion of the peer-assignment (analysing a course mate's webpage), evaluation criteria changed (S4, S6, S13). Firstly, using open environment Wikiversity does not require special training. Secondly, all participants are able to demonstrate their knowledge in the environment regulated by themselves. Thirdly, new values emerge: visibility to others, one's own prestige, sharing knowledge, altruism (Hall, 2001). These findings indicate sustainability.

Deductive content analysis revealed numerous interesting patterns, which originate from SET and influence learner's satisfaction. The first category focused on personal needs and showed that all age groups have a specific correlation between academic motivation and knowledge as well as skills acquired at the course (Table 1). The latter is not dependent on learning environment. Similar results have also been reached by Allen, Marby, Mattery, Bourhis, Titsworth and Burell (2004) and Jandaghi (2008), who studied the effectiveness of distance and traditional learning. The second category concentrates on each learner's reputation and indicates that the learners with no professional experience are the most interested in others valuing their opinions and judgements. However, the inductive content analysis of students' interviews show a clear connection between students' time management, families or job responsibilities and ICT skills. Hence, it is evident that satisfaction and sharing knowledge influence each other. The last two factors (altruism and tangible reward) have had a rather heterogeneous response. Sharing knowledge and the practical benefit of acquiring skills, which can be implemented in their profession, are valued. However, it appears that an open environment, different tools, courage to ask for help and constructive feedback and self-reflection encourage the students' self-satisfaction.

\section{Conclusion}

If a student knows and uses communication devices, it cannot be assumed that he/she is able to interact or learn in e-learning environment. We should understand that, while surfing the Internet, students have more and more access to e-tools, gaining, thus gaining more interactive experience.

The factors ensuring student's satisfaction in e-learning and looking at it in light of SET are the following: open learning environment, which enables reflection (prestige); flexible and student-centred time management (personal needs); encouraging immediate feedback, which promotes discussion (altruism); cooperation with course mates and shared 
knowledge (reward). Further research is needed on the frequency of helping questions and the balance between the explanations in determining student satisfaction in e-learning.

\section{References:}

Allen, M., Marby, M., Mattery, M., Bourhis, S., Titsworth, S., \& Burell, N. (2004). Evaluating the effectiveness of distance learning: A comparison using meta-analysis. Journal of Communication, 54, 402-420.

Artino, A. R., \& Stephens J. M. (2009). Academic motivation and self-regulation: A comparative analysis of undergraduate and graduate students learning online. Internet and Higher Education, 12, 146-151.

Astin, A. W. (1993). What matters in college? Four critical years revisited. San Francisco, CA: Jossey-Bass.

Belanger, F., \& Jordan, D. H. (2000). Evaluation and implementation of distance learning: Technologies, tools and techniques. IDEA Group Publishing: Hershey, USA; London, UK.

Boekaerts, M., Pintrich, P. R., \& Zeidner, M. (Eds.). (2000). Handbook of self-regulation. San Diego: Academic.

Bolliger, D. U., \& Martindale, T. (2004). Key factors for determining student satisfaction in online courses. International Journal on E-Learning, 3(1), 61-67.

Brookfield, S. D. (1986). Understanding and facilitating adult learning. San Francisco: Jossey-Bass Publishers.

Chong, S. M. (1998). Models of asynchronous computer conferencing for collaborative learning in large college classes. In C. J. Bonk \& K. S. King (Eds.), Electronic collaborators: Learner-centered technologies for literacy, apprenticeship, and discourse (pp. 157-182). Mahwah, NJ: Lawrence Erlbaum Associates.

Clark, R. C., \& Mayer, R. E. (2007). E-Learning and the science of instruction: Proven guidelines for consumers and designers of multimedia learning. San Franisco, CA: Pfeiffer.

Cunningham, J. (2010). Self-direction: A critical tool in distance learning. Common Ground Journal, 7(2), 89-100.

Fiedler, S., \& Kieslinger, B. (2006). iCamp pedagogical approach and theoretical background. Retrieved January 16, 2010, from http://www.icamp.eu/wp-content/uploads/2 007/05/d11__icamp___pedagogical-approach.pdf

Dabbagh, N., \& Kitsantas, A. (2004). Supporting self-regulation in student-centered Webbased learning environments. International Journal on E-Learning, 3(1), 40-47.

DeBourgh, G. A. (1999). Technology is the tool, teaching is the task: Student satisfaction in distance learning. Paper presented at the meeting of the Society for Information Technology \& Teacher Education (SITE'99) International Conference, 28 February - 4 March 1999. San Antonio, TX., USA.

Demaris, M. C., \& Kristonis, W. A. (2008). The classroom: Exploring its effects on student persistence and satisfaction. Focus on Colleges, Universities, and Schools, 2(1), 1-9. 
Dubois, J. R. (1996). Going the distance: A national distance learning initiative. Adult Learning, 8(1), 19-21.

Giese, J. L., \& Gote, J. A. (2000). Defining consumer satisfaction. Retrieved May 3, 2010, from http://www.amsreview.org/articles/giese01-2000.pdf

Hall, H. (2001). Social exchanges for knowledge exchange. Paper presented at Managing Knowledge: Conversations and Critiques, 10-11 April 2001. University of Leicester Management Centre, United Kingdom.

Hara, N., \& Kling, R. (2000). Student distress in web-based distance education. Information, Communication, and Society, 3(4), 557-579.

Homans, G. C. (1958). Social behaviour as exchange. American Journal of Sociology, 63(6), 597-606.

Jandaghi, G. (2008). The relationship between undergraduate educational system and postgraduate achievement in statistics. International Journal of Human Sciences, 5(1), 19.

Jonassen, D. H. (2004). Learning to solve problems. An instructional design guide. San Francisco, CA: Pfeiffer.

Juillerat, S. L. (1995). Investigating a two-dimensional approach to the assessment of student satisfaction: Validation of the student satisfaction inventory. Unpublished doctoral thesis, Temple University, Philadelphia, USA.

Ke, F., \& Xie, K. (2009). Toward deep learning for adult students in online courses. Internet and Higher Education, 12, 136-145.

Kikkas, K. (2009). Education technology and the disabled. Retrieved April 14, 2010, from http://www.tlu.ee/?LangID=1\&CatID=4113

Krippendorff, K. (2004). Content analysis - an introduction to its methodology (2nd ed.). Beverly Hills, CA: Sage Publications.

Mayring, P. (2000). Qualitative content analysis. Forum: Qualitative Social Research, 1(2). Retrieved May 1, 2010, from http://www.qualitativeresearch.net/index.php/fqs/article/ view/1089

Miles, M. B., \& Huberman, M. A. (1994). Qualitative data analysis. Thousand Oaks, CA: Sage.

Navarro, P., \& Shoemarker, J. (2000). Performance and perceptions of distance learners in cyberspace. The American Journal of Distance Education, 14(2), 15-35.

Niemi, H., \& Ruohotie, P. (2002). Theoretical understandings for learning in the virtual university. Hämeenlinna: Saarijärvi Offset Oy.

Pyhältö, K., Pietarinen, J., Soini T., \& Huusko, J. (2008). Luokan - aineen - ja eritysopettajat yhtennäisen perusopetuksen rakentajana [Primary education, subject and special education teachers as mainstream basic education builders]. Kasvatus, [Education], 39(3), 218-134.

Schunk, D. H., \& Zimmerman, B. J. (Eds.). (1998). Self-regulated learning: From teaching to self-reflective practice. New York: The Guilford Press.

Soini, T., Pietarinen, J., \& Pyhältö, K. (2008). Pedagoginen hyvinvointi peruskoulun opettajien työssä [Pedagogical well-being in the work of basic schools teachers]. Aikuskasvatus [Adult Education], 28(4), 244-257. 
UNESCO. (2005). Universal declaration on bioethics and human rights. Retrieved April 20, 2010, from http://portal.unesco.org/en/ev.php-URL_ID=31058\&URL_DO=DO_T OPIC\&URL_SECTION=201.html

Wang, Y. S. (2003). Assessment of learner satisfaction with asynchronous electronic learning systems. Information \& Management, 41, 75-86.

\section{Correspondence:}

Sirje Klaos, PhD student, MA, Department of Educational Science, Institute of Educational Sciences, University of Tallinn, Uus-Sadama 5, Tallinn 10120, Estonia. Tel: +372 6199 700; Fax: +372 6199 704. Email: sirje.klaos@tlu.ee 